\title{
Institutional Work Affecting Institutions in a Tourism Cluster
}

\author{
Influência do Trabalho Institucional sobre Instituições em um Cluster de \\ Turismo
}

\section{Trabajo Institucional que Afecta a las Instituciones en un Clúster de Turismo}

\author{
Márcio Jacometti ${ }^{1}$, Ellen Correa Wandembruck Lago ${ }^{1}$, Leandro Rodrigo Canto Bonfim² \\ ${ }^{1}$ Federal Technological University of Paraná (UTFPR), Curitiba, PR, Brazil \\ 2State University of Paraná (UNESPAR) Paranaguá, PR, Brazil
}

\section{Keywords:}

Institutional Work;

Tourism Cluster;

Current Institutions;

Organizational Field.

\section{Palavras-chave:}

Trabalho institucional; Cluster de Turismo; Instituições em vigor; Campo Organizacional.

\section{Palabras clave:}

Trabajo institucional; Clúster de Turismo; Instituciones Actuales; Campo Organizacional.

Peer reviewed by pairs.

Received in: 16/07/2020.

Approved in: 12/01/2021.

Editor:

Glauber Eduardo de Oliveira Santos
Abstract

This article aims at understanding how institutional work influenced the implementation of the Tourist Route Senses of Countryside (TRSC), located in two cities in Paraná, Brazil, between 2009 and 2018. It is a descriptive qualitative case study, whose data were collected through semi-structured interviews, non-participant observation, and documents, which were analyzed using thematic content analysis. Results showed that the implementation of the route was based on creation, maintenance, and interruption of institutional work, and on alteration of the regulatory, normative, and cognitive pillars of the organizational field, involving different actors (public and private). The main theoretical contribution of the research was to identify the types of institutional work and to reconcile them with typologies of institutional pillars. Also, it has practical implications for public policymakers and organizational actors, intending to establish and institutionalize a tourism cluster in rural areas, considered a source of regional economic development.

Resumo

Este artigo tem como objetivo compreender como o trabalho institucional influenciou a implementação do Roteiro Turístico Sentidos do Campo (RTSC), localizado em duas cidades do Paraná, entre 2009 e 2018. Trata-se de um estudo de caso qualitativo descritivo, cujos dados foram coletados por meio de entrevistas estruturadas, observação não participante e documentos, analisados por meio da análise de conteúdo temática. Os resultados mostraram que a implementação do percurso se baseou na criação, manutenção e interrupção do trabalho institucional e na alteração dos pilares regulatórios, normativos e cognitivos do campo organizacional, envolvendo diferentes atores (públicos e privados). A principal contribuição teórica da pesquisa foi identificar os tipos de trabalho institucional e conciliá-los com tipologias de pilares institucionais. Além disso, tem implicações práticas para formuladores de políticas públicas e atores organizacionais, com o objetivo de estabelecer e institucionalizar um cluster de turismo nas áreas rurais, considerado uma fonte de desenvolvimento econômico regional.

\section{Resumen}

Este artículo tiene como objetivo comprender cómo el trabajo institucional influyó en la implementación de la Ruta Turística Sentidos del Campo (RTSC), ubicados en dos ciudades en Paraná, Brasil, entre 2009 y 2018. Es un estudio de caso cualitativo descriptivo, cuyos datos fueron recolectados a través de semi entrevistas estructuradas, observación no participante y documentos, que fueron analizados mediante análisis de contenido temático. Los resultados mostraron que la implementación de la ruta se basó en la creación, mantenimiento e interrupción del trabajo institucional, y en la alteración de los pilares regulatorios, normativos y cognitivos del campo organizacional, involucrando a diferentes actores (públicos y privados). La principal contribución teórica de la investigación fue identificar los tipos de trabajo institucional y conciliarlos con tipologías de pilares institucionales. Además, tiene implicaciones prácticas para los formuladores de políticas públicas y los actores de la organización, con el objetivo de establecer e institucionalizar un grupo turístico en las zonas rurales, considerado una fuente de desarrollo económico regional. 
How to Cite: Jacometti, M.; Lago, E. C. W.; Bonfim, L. R. C. (2022). Institutional Work Affecting Institutions in a Tourism Cluster. Revista Brasileira de Pesquisa em Turismo, São Paulo, 16, e-2099. http://dx.doi.org/10.7784/rbtur.v16.2099

\section{INTRODUCTION}

Tourism is an important sector of the Worldwide Economy (Fundeanu, 2015; Ruhanen \& Cooper, 2004), comprising several actors and constituting a relevant source of competitive advantage for countries (Sohn, Silvestrini, Fiuza, \& Limberger, 2017), which are increasingly resorting to it as a strategy to reduce economic inequalities and generate employment and income (Aragão \& Santos, 2017; Scótolo \& Panosso Netto, 2015). In the Brazilian context, previous studies state that tourism routes can be a relevant source of regional economic development (Santos \& Pereira, 2018), which is essential for promoting an increase in the income of poorer communities (Malta, Braga, \& Barbosa, 2019) and improving the quality of life of the citizens of touristic areas (Guimarães \& Morano, 2020; Ribeiro et al., 2020).

Rural tourism, specifically, is considered a relevant complement to the main productive activity of small rural properties (Beni, 1999; Padilha, Corte, \& Souza, 2019; Tonini \& Dulci, 2020), becoming an alternative source of income for small-land owners and increasing the economic relevance of the region as a whole (Serviço Brasileiro de Apoio às Micro e Pequenas Empresas [SEBRAE], 2014). As shown by Aragão and Santos (2017, p. 271), family farming and rural tourism have been drawing interest in many developing countries, what is not an exemption in Brazil, where it represents an important mechanism in which "the rural producer becomes an entrepreneur and a tourism service provider, being able to work directly in the conservation of the environmental and cultural heritage of his/her region".

Considering the need to expand the rural tourism sector in Brazil, the Federal Government launched in 2009 a project called "Talents of Rural Brazil", which aimed at promoting the collective interests of Brazilian tourism firms (Lago et al., 2018; Sanches et al., 2018). This public policy was based on the implementation of actions to strengthen the relationship between family farming and tourism, promoting the insertion of these products and services in the Brazilian tourism market (Ministério do Turismo, 2015). As a result of the project, 23 tourist routes were formalized throughout Brazil to attract tourists to the surroundings of the host cities of the 2014 Soccer World Cup (SEBRAE, 2014), including the Tourist Route Senses of the Countryside (TRSC), located in Quatro Barras and Campina Grande do Sul, two municipalities in the City of Curitiba Metropolitan Area, State of Paraná, Brazil. This tourist route was formed by small tourism firms in the sectors of agribusiness and ecological tourism in the region (Lago et al., 2018).

The development of a tourist route is relevant for local business communities because it gives them a sense of identity and belonging (Carvalho, 2015; Jafari, 1987). Moreover, it provides defined and structured purposes for the planning, management, promotion, and commercialization of tourism in rural areas (Ministério do Turismo, 2007). Given the relevance that such tourist routes represent for the economical and local development (Aragão \& Santos, 2017; Santos \& Pereira, 2018), analyzing its process of implementation from an institutional perspective can provide relevant evidence of how collective action can influence an existing organizational field, which is the set of organizations that integrate some aspect of institutional life (DiMaggio \& Powell, 1991).

Thus, this article aims at describing the formalization of the TRSC and the behavior of the route's actors, explaining how collective institutional work has influenced its implementation. The relevance of this research is justified due to the importance that tourist routes represent for the local development and sustainability of micro, small and medium enterprises (SMEs) since tourist agglomerations are important mechanisms for the promotion of local and regional-level rural communities.

\section{THEORETICAL BACKGROUND}

The institutional theory is one of the approaches with the greatest capacity for explaining organizational phenomena (Eisenhardt, 1988; Lawrence \& Suddaby, 2006). It provides the opportunity to understand how institutional context shapes organizational beliefs, values, and actions. Additionally, it helps in understanding how social processes and 
representations become rules in certain organizations, offering the possibility of identifying interesting insights to understand social phenomena.

The institutional environment is considered unitary and consistent (DiMaggio \& Powell, 2005; Meyer \& Rowan, 1977 ) and it is related to cognitive-cultural, regulatory and regulative elements that, associated with the activities and resources, give meaning to social life (Scott, 2002). Elements that comprise the institutional environment are related to how social conduct is regulated, to the standards recognized by the group, to the bases for legitimizing social roles and activities, to the laws and sanctions applied, among other elements (Scott, 2002), being 1understood as a guide to drive organizational actions (Jacometti, Gonçalves, \& Castro, 2014; Marietto \& Serra, 2019).

Despite its importance for organizational research, previous literature shows that institutional theory is still being neglected in the field of tourism (Falaster, Zanin, \& Guerrazi, 2017), specifically considering how institutions can affect how the public policies for tourism in general and the touristic routes and destinations in specific can be seen as legitimate (Endres \& Pakman, 2019; Pimentel, Carvalho \& Pimentel, 2019). In this regard, questions regarding how entrepreneurs are embedded in and help to configure tourism organizational fields (Cintra, Amâncio-Vieira, \& Costa, 2016) or how tourism actors can work to change institutions through entrepreneurial efforts and collective action (Jacometti et al., 2017) are yet to be discussed further in the tourism literature. Thus, we will discuss these concepts in more detail in the following sections.

\subsection{Organizational Field}

The organizational field, according to Scott (2004), is comprised of a set of organizations that operate in a functionally specific environment, associated with their exchange partners, financiers, and regulators, so that the existing interaction among these actors occurs in a more significant and frequent way than the interactions occurred with those outsiders of the field. Moreover, the organizational field is embedded in a broader social environment that allows organizations to glimpse who are the actors, organizations, and institutions of the field, as well as identifying what are their goals, interests and how they can exercise some influence (DiMaggio \& Powell, 2005) on other organizations and on the field itself. According to Medeiros, Alves, \& Farah (2015), organizations can shape their organizational field by favoring the entry of others that have different views from the current field's standard, in the same way, that they can exclude from the field those organizations that do not fit the interests of the current model.

Considering the broadness of theoretical approaches to organizational fields, Machado-da-Silva, Guarido Filho, \& Rossoni (2006) classified them into six theoretical perspectives, namely: (1) as the totality of relevant actors; (2) as a functionally specific arena; (3) as a center for dialogue and discussion; (4) as an arena of power and conflict; (5) as an institutional sphere of disputed interests; and (6) as a structured network of relationships. The authors emphasize that the idea of the field is in constant development and although there are different approaches, they are not exclusive, but "define their provisional and contingent character" (Machado-da-Silva et al., 2006, 136), demonstrating that the definition is still up for many research and debates. The concept of organizational field adopted in this research comprises the organizational field as a set of organizations that integrate some aspect of institutional life (DiMaggio \& Powell, 1991). Such interactions can be understood as the collective actions performed by social actors, evidenced by the concept of institutional work (Lawrence \& Suddaby, 2006).

\subsection{Institutional Work}

The focus of institutional work is concentrated on the agency dimension through the involvement of actors in processes of institutional change through physical and mental efforts, to affect institutions (Baratter, Ferreira, \& Costa, 2010). Therefore, individuals and organizations that are involved in the creation, interpretation, maintenance, and change of institutional rules and standards can provide collective responses to the environment (Coraiola, Jacometti, Baratter, \& Gonçalves, 2015; Hasselbladh \& Kallinikos, 2000; Lawrence \& Suddaby, 2006; Scott, 1994).

Institutional work scholars seek to clarify the role of the agency in the institutional dynamics (Coraiola et al., 2015), that is, its focus is on understanding how action influences the existing social and institutional structures through the work of individuals, groups, and organizations to promote the creation, maintenance or disruption of institutions (Lawrence, Suddaby, \& Leca, 2009; Moisander, Hirsto, \& Fahy, 2016). In this stream of research, institutional creation is the category that has been drawing the most attention from organizational scholars (Coraiola et al., 2015; 
Lawrence \& Suddaby, 2006), specifically regarding understanding the necessary characteristics and conditions for the emergence of new institutions. Moreover, institutional work involves the construction of rules and their inherent rewards and sanctions (Canning \& O'Dwyer, 2016). It is considered a political work where rules are reconstructed, property rights and borders that give access to material resources are defined, belief systems are reconfigured, abstract categorizations and boundaries of the systems of meaning are amended (Lawrence \& Suddaby, 2006; Lawrence et al., 2009).

Building upon the categorization proposed by Lawrence and Suddaby (2006), Jacometti (2013) reclassified them following the institutional regulatory, normative, and cultural-cognitive pillars presented by Scott (2008). From this perspective, the regulative institutional creation work comprises the use of activities that aim to rebuild rules, property rights, and access to material resources (Jacometti et al., 2014). In this pillar, it is possible to identify the acquisition, definition, and defense institutional works.

The normative pillar analyzes the construction of professional identities, as well as the development of standards, practices, and technologies that are concurrent or complementary to existing institutions. According to the authors, this pillar includes the types of action aimed at building identities, changing norms, and building networks. It focuses on the organizational normative structure and emphasizes actions that reconfigure the actors' systems of norms.

The cultural-cognitive pillar, in turn, is related to the changes in the systems of meaning through the adoption of newly taken for granted practices along with the education of individuals involved in the process using their skills and knowledge for marshaling support for new institutions. The kinds of institutional creation work inherent to this pillar are mimicry, theorization, and education, which can reveal the cognitive side of the institutions by changing their system of meanings (Scott, 2008). Table 1 presents the classification of the types of institutional creation work proposed by Lawrence and Suddaby (2006) and categorized by Jacometti (2013) based upon the institutional pillars presented by Scott (2008).

Table 1 - Pillars, typology and definition: institutional creation work

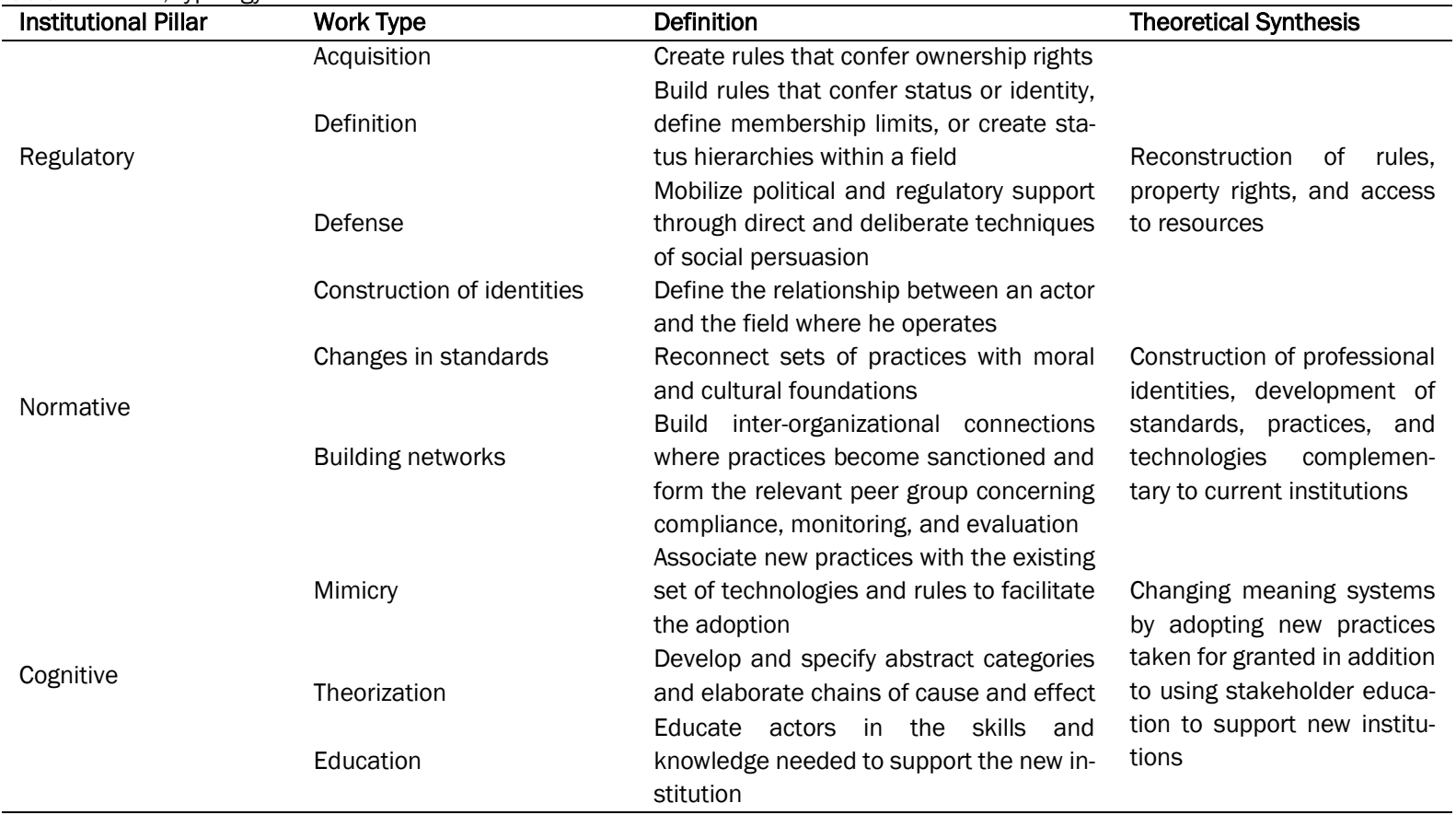

Source: adapted from Jacometti (2013), Lawrence and Suddaby (2006), Scott (2008).

According to Lawrence and Suddaby (2006), institutional maintenance work has drawn less attention than creation work. However, the most powerful institutions resort to it for being relevant and effective. Moreover, understanding the maintenance work is essential to evaluate the social conduct of the actors embedded in the institutional environment (Coraiola et al., 2015).

Institutional maintenance work refers to the efforts of the actors to support, repair, and recreate social mechanisms that make it possible to sustain existing institutions (Canning \& O'Dwyer, 2016; Lawrence et al., 2009). Thus, this type is usually triggered by the threat of a possible change in the current institutional arrangements and is related 
to resistance actions aimed at neutralizing threats to prevent changes and challenges in the status quo (Micelotta \& Washington, 2013) of organizations.

Lawrence and Suddaby (2006) mention that regulatory institutional maintenance work includes permission, policing, and deterrence; the normative covers mythologization and incorporation and routinization; while the cognitive includes aspects inherent to valorization. And that institutional maintenance work involves preserving and strengthening existing institutions to comply with established standards regarding rules, standards, and beliefs. Table 2 illustrates the types of institutional maintenance work presented by authors.

Table 2 - Pillars, typology and definition: institutional maintenance work

\begin{tabular}{|c|c|c|c|c|}
\hline Institutional & Pillar & Work Type & Definition & Theoretical Synthesis \\
\hline \multirow{3}{*}{ Regulatory } & & Permission & $\begin{array}{l}\text { Create rules that facilitate, complement, } \\
\text { and support institutions }\end{array}$ & \multirow{6}{*}{$\begin{array}{l}\text { Preservation of existing institu- } \\
\text { tions by complying with stand- } \\
\text { ards by submitting to rules, } \\
\text { norms, and standards }\end{array}$} \\
\hline & & Policing & $\begin{array}{l}\text { Ensure compliance through enforce- } \\
\text { ment, auditing, and monitoring }\end{array}$ & \\
\hline & & Dissuasion & $\begin{array}{l}\text { Establishing coercive barriers to institu- } \\
\text { tional change }\end{array}$ & \\
\hline \multirow{2}{*}{\multicolumn{2}{|c|}{ Normative }} & Mythologization & $\begin{array}{l}\text { Preserve the normative foundations of an } \\
\text { institution, creating and sustaining myths } \\
\text { about its history }\end{array}$ & \\
\hline & & $\begin{array}{l}\text { Incorporation and routi- } \\
\text { nization }\end{array}$ & $\begin{array}{l}\text { Infuse the normative foundations of an } \\
\text { institution in the participants' daily lives } \\
\text { and organizational practices }\end{array}$ & \\
\hline Cognitive & & Valuation & $\begin{array}{l}\text { Provide positive and negative examples } \\
\text { that illustrate the regulatory foundations } \\
\text { of an institution }\end{array}$ & \\
\hline
\end{tabular}

Source: adapted from Jacometti (2013), Lawrence and Suddaby (2006), Scott (2008).

The institutional work carried out by the actors to cause the rupture of institutions is the least explored category in the literature (Lawrence \& Suddaby, 2006; Lawrence et al., 2009), despite having great importance for understanding the role played by actors in the process of institutional disruption.

This kind of work involves the action of individuals to attack or undermine the incumbent institutions (Canning \& O'Dwyer, 2016). However, this rupture can occur to preserve or strengthen a current "institutional constellation" (Coraiola et al., 2015, 706). The actors involved in this process seek to disassociate practices, rules, and technologies from the moral foundations of the institutions and undermine the fundamental premises and beliefs that stabilize them (Lawrence et al., 2009).

According to Oliver (1992), deinstitutionalization is a process by which institutions weaken and disappear, causing the discontinuity of an existing organizational practice or activity and can be motivated by the understanding that certain practices carried out by organizations no longer meet the needs and expectations of particular organizations.

For Lawrence and Suddaby (2006), the actors responsible for proceeding with the institutional disruption work are those who do not have the interests served by current institutional arrangements and concentrate their forces on the process of disrupting them. Table 3 shows the classification of the types of institutional disruption work that exist according to Lawrence and Suddaby (2006), categorized by Jacometti (2013), based on the institutional pillars presented by Scott (2008).

Table 3 - Pillars, typology and definition: institutional disruption work

\begin{tabular}{|c|c|c|c|}
\hline $\begin{array}{l}\text { Institutional Pillar } \\
\text { (Scott, 2008) }\end{array}$ & Work Type & $\begin{array}{l}\text { Definition } \\
\text { (Lawrence and Suddaby, 2006) }\end{array}$ & $\begin{array}{l}\text { Theoretical Synthesis } \\
\text { (Jacometti, 2013) }\end{array}$ \\
\hline Regulatory & Disconnection of sanctions & $\begin{array}{l}\text { Work to disconnect rewards and sanctions from } \\
\text { any set of practices, technologies, or rules } \\
\text { Disassociate the practice, rules, or technology }\end{array}$ & $\begin{array}{l}\text { Actions aimed at breaking } \\
\text { existing institutions and } \\
\text { starting deinstitutionaliza- }\end{array}$ \\
\hline Normative & Untying of moral foundations & $\begin{array}{l}\text { from their moral basis, as appropriate, within a } \\
\text { specific cultural context }\end{array}$ & $\begin{array}{l}\text { tions by disconnecting sanc- } \\
\text { tions from the rules, untying }\end{array}$ \\
\hline Cognitive & Questioning & $\begin{array}{l}\text { Decrease perceived risks of innovation and dif- } \\
\text { ferentiation, undermining key assumptions and } \\
\text { beliefs }\end{array}$ & $\begin{array}{l}\text { moral foundations from the } \\
\text { norms, and destabilizing be- } \\
\text { liefs and values }\end{array}$ \\
\hline
\end{tabular}

Source: adapted from Jacometti (2013), Lawrence and Suddaby (2006), Scott (2008). 
After the presentation of the principles of institutional work that served as the basis for this study, the methodological procedures adopted are then presented.

\section{RESEARCH METHODS}

This article aims at describing the formalization of the TRSC and the behavior of its actors, explaining how collective institutional work has influenced its implementation. As this research question involves the interaction between social actors, the qualitative approach was adopted because it is the most adequate to understand the complexity of the object of this study in its natural setting, being interpreted according to the most diverse meanings. Moreover, the interpretative approach admits the understanding of multiple realities, which are socially constructed and modified through personal interactions (Denzin \& Lincoln, 2006).

The research strategy used was the case study, because it allows to carry out a deep analysis about the phenomenon (Vilelas, 2009), whose objective, according to Stake (2009), is to make the case understandable through its particularization. Given its great tourist potential and its importance for the region, the case under analysis is the TRSC. This research is descriptive, due to the need to describe and evaluate several aspects, dimensions, or components of the investigated phenomenon (Triviños, 2008; Vilelas, 2009), to observe and describe the behaviors (Freixo, 2009) of the actors, and to access the relationship between the analytical categories (Gibbs, 2007).

As it was formalized in 2014 , it was possible to carry out a longitudinal study on how the institutional work influenced the implementation of the route. The longitudinal perspective was adopted to analyze the events and define the patterns that occur through a temporal analysis (Van de Ven \& Poole, 1995). The longitudinal data ranges from 2009 (launch of the public policy for creating the tourist itinerary) until July 2015, after the formalization of the route. The level of analysis of the research is field-level and the unit of analysis comprises the social actors who followed the process of formalizing the TRSC, in 2014 through a project developed by the Federal Government called "Talents of Rural Brazil". Located in the municipalities of Quatro Barras and Campina Grande do Sul, in the State of Paraná, the route is comprised of seven tourist developments focused on agribusiness and ecological tourism.

The data was collected through non-participant observations that took place from August 2015 (when it started the researcher's contact with the phenomenon) until June 2018 (the period in which data collection was completed). In non-participant observation, the researcher is present in the same location as the respondents to observe them without interfering or performing the same activities of the respondents (Stacey, 1977). Overall, the observations were held in regular and extraordinary meetings lasting approximately 90 minutes each, generating 24 pages of field notes. The observation period made it possible to meet the members of the route and become familiarized with the research setting (Shah, 2006).

Additional data were collected through semi-structured interviews with the relevant actors involved in the development of the TRSC. The interviews were held in June 2018 and additional data was collected until achieving data saturation, that is, when no new information was arising from the additional interviews (Minayo, 2008). The sample of actors defined as interviewees took into account the factors listed by Triviños (2008), that is, the sample includes various actors in the organizational field who played important roles in formalizing the TRSC, namely: a representative of the City Hall of Quatro Barras (PMQB) and four representatives of tourism firms. Although other actors from the field were also identified (e.g., service providers, customers, financial institutions), observational and archival data reveal that they didn't have decision-making or any veto power during the meetings held for creating and formalizing the TRSC.

According to Laville and Dionne (1999), the semi-structured interview is the most usual type of interview and is characterized by the use of a script containing themes and questions, being allowed to change the questions that the interviewer deems necessary (Bryman \& Bell, 2011). The five interviews conducted lasted 25 minutes each, resulting in 20 pages of transcribed data.

Beyond observations and interviews, archival data were also collected, since they are appropriate tools for data collection in case studies (Stake, 2009) and help the researchers to confront the data with the accounts of the research interviews. To make a correct reading of the reality presented, data were triangulated for the sake of scientific rigor, triangulating (1) sources of evidence; (2) researchers; (3) theories; and (4) methods (Stake, 2009), through thematic content analysis (Mozzato \& Grzybovski, 2011; Bardin, 2009). Data were triangulated through the analysis of interviews, observations, meeting minutes, media articles, and advertising flyers. 


\section{DATA ANALYSIS AND RESULTS}

The Brazilian Government developed, in October 2009, a project called "Talents of Rural Brazil", which was the result of the Technical Cooperation Agreement between the Ministry of Tourism, Ministry of Agrarian Development, and SEBRAE, in partnership with the Ministry of Environment and German Technical Cooperation Agency (GTZ) (Ministério do Desenvolvimento Agrário, 2017; Ministério do Turismo, 2015; SEBRAE, 2014).

The project consisted of implementing joint actions to identify, order, promote, and strengthen the relationship between family farming and tourism, adding value to these products and services and qualifying, supporting, and structuring tourist routes composed of, at least, $10 \%$ of the city's Brazilian farming families (Ministério do Turismo, 2015). Although it was launched through a Public Call published by SEBRAE in November 2010, in 2008, the municipality of Quatro Barras already had a proposal for a tourist route called "Historic Routes of the Mountains", aimed at rescuing the routes used by indigenous and colonizers between the capital (Curitiba) and the coast of the State of Paraná (Bem Paraná, 2008).

Seeking legitimacy in the tourist scene in the state of Paraná, the Quatro Barras municipality promptly became interested in competing for the Public Call, which occurred through the registration of the existing route. The final result was released in May 2012, when the selection of the tourist itinerary for the City of Quatro Barras was confirmed. According to the Ministry of Tourism (Ministério do Turismo, 2016), the project provided several benefits to the enterprises that are part of the tourist itineraries in regards to the development of the technical and institutional environment of the organizations (DiMaggio \& Powell, 2005; Scott, 2002; 2008; Scott \& Meyer, 1983). The project provided financial resources to institutionalize the route through information sharing, increased competitive capacity, access to new markets, and development of new products and services.

The initial intention of the entrepreneurs who part of the TRSC was to increase the tourist demand of Quatro Barras and Campina Grande do Sul through the 2014 Football World Cup that was held in Curitiba since the cities are located in Curitiba's metro area, which made viable the access of tourists. However, there was a disappointment about the touristic balance of the World Cup in the region, as both the enterprises and the city halls had high expectations and were prepared to host a high number of tourists, which did not materialize.

Despite the expectations not being met due to the low flow of tourists in the region, the entrepreneurs followed the script, developing some joint actions, organizing subgroups, articulating with the municipal public authorities, planning meetings and events aiming at the expansion of the enterprises and the region as a whole (Associação Industrial e Comercial de Quatro Barras e Campina Grande do Sul [QBCAMP], 2018).

Figure 1 - Relationships network of the organizational field of the TRSC in its formalization in 2014

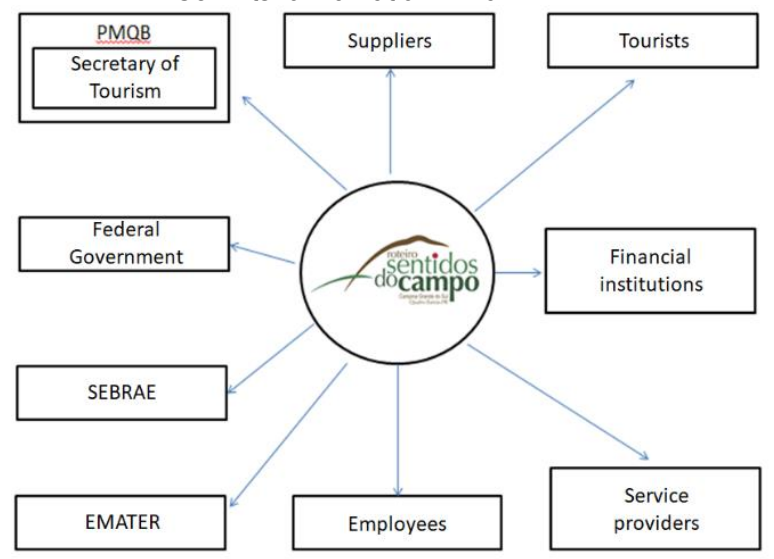

Source: prepared by the authors.

According to the theoretical lens adopted in this work, which understands the organizational field as a functionally specific arena (Scott, 2004). The actors involved in the field identified were divided into two stages, namely: the first one identified the actors on the field in the year of its formalization (i.e. 2014), and the second stage identified configuration of the actors that are part of the organizational field in the year 2018. The advantages of Scott's (2004) perspective regarding the organizational fields consist of enabling the institutional and technical delimitation of the organizational environment, improving the field analysis (Machado-da-Silva et al., 2006). Figure 1 shows the actors that were identified through document analysis and in the interviews in the formalization stage of the TRSC. Regarding the degree of the relationship, the analyzes allowed to identify that, in this stage, there was a strong 
relationship of the tourist route actors with the Federal Government, Quatro Barras City Hall (through the Municipal Secretary of Tourism), and SEBRAE.

The data allowed the inference that the Federal Government, SEBRAE, and EMATER (Instituto Paranaense de Assistência Técnica e Extensão Rural) had quit the organizational field after the implementation of the TRSC, as Figure 2 shows. This is because, as it is a public policy that dealt with the creation of tourist routes for the World Cup, as soon as the project was completed and the objectives were achieved, there was no longer a need for these bodies to continue composing analyzed field.

Figure 2 - Relationships network of the organizational field of the TRSC in its maintenance in 2018

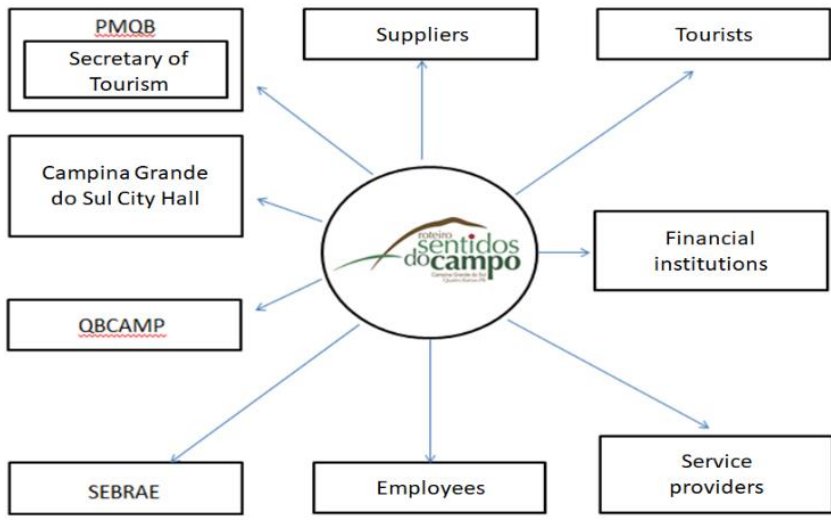

Source: prepared by the authors.

However, with the development of the cluster, organizations have been shaping the organizational field, allowing new actors to integrate it (Medeiros et. al, 2015; Novelli, Schmitz, \& Spencer, 2006) and forming a new network of relationships.

Thus, based on the document analysis, interviews, and observations, it was found that the Municipality of Campina Grande does Sul and the Industrial and QBCAMP became part of the network. Due to the structure, composition, and potential of the tourist cluster, in 2015 there was a proposal by professors from the Federal University of Paraná (UFPR) and the Federal Technological University of Paraná (UTFPR) to assist the members of the TRSC in the formalization of a Local Productive Arrangement (LPA) like a cluster. The proposal included support, training, and monitoring provided by the institutions' professors and researchers. However, it demanded the commitment from the entrepreneurs to carry out some specific actions, aiming at the full understanding of the project, the acceptance, and the adequacy of the enterprises in what was necessary to implement an LPA.

After some explanations and detailed presentations of the proposal, the group met and agreed to start the necessary procedures for the implantation of a tourism LPA on the route. However, shortly afterward, they have declined the proposal and rejected the aid. Thus, as the project was not carried out, the universities were not included in the network of relationships in the organizational field.

Machado-da-Silva et al. (2006) asserted the established network allowed the definition of the boundaries of the organizational field of the TRSC. Thus, the boundaries of this field were delimited by the presence of organizations that work in the tourist industry of the region of Quatro Barras and Campina Grande do Sul, or that perform adjacent functions related to tourist activities, as well as those organizations that maintain some relationship with touristic organizations and businesses.

The data allowed the identification of the main actions developed by the members of the organizational field in which the route was inserted, was the institutional creation work, since 39 out of 57 codes from documents, interviews, and observations, corresponded to actions aimed at creating institutions (68\%), 14 represented the institutional maintenance work (25\%), and 4 occurrences referred to the institutional disruption work (7\%). Identifying the types of institutional work carried out in the field was essential to provide a holistic view of the events that triggered the institutionalization of TRSC. Institutional work carried out by the TRSC's actors were identified and are presented below, according to the typology of Lawrence and Suddaby (2006): creation, maintenance and disruption; and with Scott's (2008) regulatory, normative and cognitive pillars, in the model proposed by Jacometti (2013). 
The regulatory institutional creation work refers to the reconstruction of rules, property rights, and access to material resources, which can be evidenced in the TRSC by the presence of the types of institutional work of acquisition, definition, and defense.

The normative institutional creation work concerns the construction of professional identities, the development of norms, practices, and technologies that are complementary to the incumbent institutions and keeps the focus on the organizational normative structure, and emphasizes the actions capable of reconfiguring the actors' normative systems.

Regarding the "identity construction" category, the presence of two distinct types of identities was observed in the group, one characterized by the ventures that believed and worked in favor of the development and maintenance of the TRSC, and the other represented by the entrepreneurs that did not share the same ideas and began to deny the efficacy of the results obtained by the cluster.

The cognitive institutional creation work is related to the changes in the systems of meaning, through the adoption of newly taken for granted practices and through the education of individuals involved in the process who use their skills and knowledge to support new institutions.

Table 4 - TRSC institutional creation work

\begin{tabular}{|c|c|c|}
\hline Institutional Pillar & WorkType & Institutional Work Description \\
\hline \multirow{3}{*}{ Regulative Work } & Acquisition & $\begin{array}{l}\text { It was diagnosed considering the desire of group members to acquire unique } \\
\text { benefits provided by municipal governments to obtain advantages over other } \\
\text { projects in the same segment that are not a part of the network, favoring only } \\
\text { the companies from the TRSC }\end{array}$ \\
\hline & Definition & $\begin{array}{l}\text { It was detected by the actions carried out by the enterprises aimed at placing the } \\
\text { TRSC in a prominent position in the region where it is inserted, evidencing and } \\
\text { strengthening its image in the overall society to legitimize it in the organizational } \\
\text { field }\end{array}$ \\
\hline & Defense & $\begin{array}{l}\text { It consisted of obtaining the support of municipal governments for the realization } \\
\text { of the projects idealized by the network. The volume of actions identified also } \\
\text { showed the interdependence that exists between tourism enterprises and mu- } \\
\text { nicipal executive power, contrary to the guidelines of the technicians from the } \\
\text { Ministry of Culture }\end{array}$ \\
\hline \multirow{3}{*}{ Normative Work } & Identity construction & $\begin{array}{l}\text { The collective actions were made possible by the strengthening of the relation- } \\
\text { ships between the tourist enterprises, which generated the unification of the } \\
\text { group and new business relationships, besides the actions developed aiming at } \\
\text { the adhesion of new participants, which reinforced the identity of the route's } \\
\text { tourist enterprises }\end{array}$ \\
\hline & Standard changes & $\begin{array}{l}\text { It was identified by actions aimed at promoting changes in existing practices } \\
\text { through specialized consultancy and through the adoption of joint strategies } \\
\text { aimed at determining common goals that trigger changes desired by the mem- } \\
\text { bers of the route }\end{array}$ \\
\hline & Network building & $\begin{array}{l}\text { It was diagnosed by visitations made by entrepreneurs in all the organizations } \\
\text { TRSC, which generated mutual knowledge about the products and services de- } \\
\text { veloped by the members. Such actions enabled the construction of a business } \\
\text { network in the field, made possible by the customers' referral regarding the ser- } \\
\text { vices provided by the companies included in the route and through the purchase } \\
\text { of inputs produced by rural entrepreneurs, by local hotels and restaurants }\end{array}$ \\
\hline \multirow{3}{*}{ Cognitive Work } & Mimicry & $\begin{array}{l}\text { It was identified by the imitation of procedures and conducts adopted by other } \\
\text { organizations already legitimized in the tourist sector of the region, as well as } \\
\text { through the adoption of mimetic processes among the members of the route } \\
\text { aiming at the standardization and characterization of the enterprises }\end{array}$ \\
\hline & Theorization & $\begin{array}{l}\text { It was identified by the need to define the profile of the tourists who visit the } \\
\text { region to outline strategies to increase the permanence of these visitors in tourist } \\
\text { developments, as well as to attract new customers }\end{array}$ \\
\hline & Education & $\begin{array}{l}\text { It was recognized by holding meetings encouraging the formalization of the busi- } \\
\text { nesses belonging to the organizational field that were operating informally by the } \\
\text { training carried out by the Ministry of Tourism's technical advisory services aimed } \\
\text { at teaching entrepreneurs how to improve the provision of services to tourists }\end{array}$ \\
\hline
\end{tabular}

Source: prepared by the authors.

As Table 4 shows, data analysis allowed to verify that all types of institutional creation work presented by Lawrence and Suddaby (2006) were identified empirically in the tourist cluster, demonstrating that the members of the organizational field can promote institutional changes (Hoffman, 1999) to create institutions.

The regulatory institutional maintenance work, on the other hand, consists of the efforts made by the actors to support, repair, and recreation mechanisms that allow the support of the incumbent institutions in the organizations. 
Types of institutional maintenance work are related to the preservation and strengthening of existing institutions and are composed by social actions of permission, policing, and deterrence, which were grouped according to the collective efforts performed by actors in the analyzed field. The normative institutional pillar that encompasses the types of institutional work aimed at maintaining institutions refers to mythology and incorporation and routinization. For this category, only one type was identified in the organizational field, and no evidence was found to prove the presence of mythologization, as no actions aimed at preserving the historical memory of the route were identified. As revealed by the research data, the participants did not know the foundation history, the actors involved, and not even the institutionalization process of the TRSC. The cognitive institutional maintenance work, in turn, involves aspects inherent to social actions related to valorization, which aim to provide positive and negative examples that illustrate the normative foundations of an institution.

As Table 5 shows, the institutional maintenance work identified in the research demonstrated that the actions performed by the actors inserted in the organizational field are related to resistance to changes, aiming at the neutralization of possible threats that can alter the status quo of the current context.

It was also demonstrated that the actors performed joint actions aimed at, supporting, repairing, and recreating mechanisms to sustain the incumbent institutions, showing some reluctance of the actors to accept possible changes in the institutional condition in place.

The institutional disruption work consists of the action taken by the social actors to attack the existing institutions, seeking to disassociate practices, rules, and technologies from the institutionalized moral foundations and undermine the fundamental premises that stabilize the institutions. This type of institutional work includes actions developed to break the incumbent institutions and ignite deinstitutionalizations by disconnecting sanctions from the rules, disconnecting moral foundations from the rules, and destabilizing beliefs and values.

Table 5 - TRSC institutional maintenance work

Institutional Pillar Work Type

Institutional Work Description

It was identified by the decisions that defined the creation of rules and criteria among the participants to promote the strengthening of the TRSC. Those norms required the entrepreneurs to adjust and conform to the inherent standPermission ardization among members, to the disclosure of the activities of each development, to the strengthening of the organizations through the adhesion of new companies, to the participation in the meetings and the commitment to keeping up to date the monthly payments to QBCAMP

It was detected by the participation of businessmen in Tourism Councils whose objective is to promote the inspection and monitoring of actions aimed at tourism development in the region, as well as by defining the criteria for continuity in the route, requiring a financial commitment from each enterprise to QBCAMP and effective participation in the decisions taken by the members by attending the meetings. The policing work is carried out effectively since the data collected made it possible to identify that the default in monthly fees resulted in the shutdown of some entrepreneurs from the route, even though they would still consider themselves part of it

Regulative Policing

Work

Dissuasion

Normative

Work

Incorporation and routiniza-

tion

Cognitive

Work

Valuation
It was diagnosed by the recurring conduct of one of the entrepreneurs selected to postpone, and finally, to refuse the interview to the researchers, showing resistance when providing information that could reveal possible weaknesses in the cluster, as he is an actor who manifested a leadership profile in the group. The collective decision not to accept technical and specialized support for the formalization of a tourism LPA in the region also highlighted this type of institutional work, expressing great resistance to change of the current status quo

It was identified by the invitation made to tourist enterprises in the region to join the route, by all the rules that governed the group was exposed so that, if they accepted to be a part of the cluster, they would already be subject to the incumbent institutions. Another action refers to the collective efforts of all participants in the route to obtain a tourist certification, as the adoption of this practice proved to be effective and provided positive returns to one of the TRSC's enterprises with such a tourist seal

Exposition of examples and benefits provided to members of the TRSC to extoll the advantages of integrating the cluster and attracting new entrepreneurs. Another evidence is that the use of social media provided benefits to a tourism enterprise that is a member of the route, as the promotion attracted new customers and was considered a successful case to be imitated

Source: prepared by the authors.

This situation denotes the occurrence of a history of deinstitutionalization of an organizational aspect, due to the political pressure for increased innovations, triggered by the proposal to formalize an LPA in that organizational field. Regarding the normative institutional disruption work, it was found that such behavior can also be classified as a 
process of deinstitutionalization through political pressure at the organizational level, where conflicting internal interests arise as were reported by the interview data.

This was because the social agent lost the will to maintain or recreate institutionalized organizational activity for feeling that the practices failed to meet their needs and expectations.

This action also showed the process of deinstitutionalization carried out by the actors, which can cause the weakening or disappearance of existing institutions. Such attitude can be classified, according to the history of deinstitutionalization, as social pressure for an increase in the structural breakdown, due to the conflicts and ruptures caused by disagreements regarding the strategic direction that the group should follow.

\begin{tabular}{|c|c|c|}
\hline Institutional Pillar & Work Type & Institutional Work Description \\
\hline $\begin{array}{l}\text { Regulative } \\
\text { Work }\end{array}$ & Disconnections of sanctions & $\begin{array}{l}\text { It was identified from the moment the group declined the idea of formalizing } \\
\text { a Tourism LPA despite the advantages presented, and this action took place } \\
\text { to preserve the current situation of the organizational field. }\end{array}$ \\
\hline $\begin{array}{l}\text { Normative } \\
\text { Work }\end{array}$ & Disconnecting moral foundations & $\begin{array}{l}\text { Was identified by the insistence of one of the entrepreneurs to demonstrate } \\
\text { that the route did not bring benefits or gave advantages to his enterprise, so } \\
\text { he tried to disassociate the existing beneficial practices as being null, disre- } \\
\text { garding the collective gains mentioned by other entrepreneurs to reject the } \\
\text { institutionalization of TRSC }\end{array}$ \\
\hline $\begin{array}{l}\text { Cognitive } \\
\text { Work }\end{array}$ & Questioning & $\begin{array}{l}\text { It was identified by the efforts of the actors to disrupt the institutions and was } \\
\text { perceived by the departure of one of the TRSC's enterprises under the allega- } \\
\text { tion that the company's participation in the cluster did not add benefits to } \\
\text { their business. It is noteworthy that companies that also left the network later } \\
\text { shared or were influenced by this decision }\end{array}$ \\
\hline
\end{tabular}

The analysis of the types of institutional disruption work held in the organizational field showed that the collective actions and efforts aimed at disrupting institutions were carried out by the actors whose interests were not served by the institutional arrangements and performed to preserve the status quo in place in the TRSC, as Table 6 shows.

Thus, the data demonstrated that the social actors that are part of the organizational field can act in favor of institutional changes aimed at breaking with the existing institutions as a form of protection and resistance to possible changes that may arise further.

\section{DISCUSSION AND CONCLUSION}

This research aimed to understand how the collective institutional work has influenced the implementation of the TRSC since its formalization. The theoretical lenses used refers to the assumptions of institutional theory regarding the social actors' agency capacity through the institutional work, which can be held to promote the creation, maintenance, or disruption of social institutions in the context of tourism.

After conducting an empirical study it was identified that institutional work influenced the implementation of TRSC due to the capacity of rational action by social actors. However, this implementation process is not fully consolidated. It was observed that the main actions were related to the institutional works of creation and maintenance, performed by the relevant actors involved in the process, namely: Municipal Secretary of Tourism of Quatro Barras, Federal Government, and business owners from the tourism sector of the region of Quatro Barras.

The Municipal Secretary of Tourism and the Federal Government aimed at the creation of norms and rules to define property rights, allowing the group's access to material resources (Lawrence \& Suddaby, 2006; Lawrence et al., 2009), such as financial investments from the Talents of Brazil Rural project. The institutional work carried out by the tourism entrepreneurs was identified as being of institutional creation and maintenance, denoting the need to build the identity of the group that was in the creation phase, as well as supporting the rules in place (Lawrence \& Suddaby, 2006).

The fact that the main actors involved in the implementation of the TRSC are inducing agents of the tourism sector shows the presence of the top-down model of public policy implementation, which occurs when the actions are carried out by government representatives, which requires greater control over the actors involved (Mazmanian \& Sabatier, 1981), as well as bringing back into discussion the role played by the State in the public decision-making process (Lascoumes \& Les Galés, 2014), which is aligned with extant literature in tourism (Lima, Irving, \& Abreu, 2017; Pimentel, Carvalho, \& Pimentel, 2019). 
In the stage of development and maintenance of the route, the collective actions developed by the entrepreneurs corresponded to the efforts aimed at promoting the creation, the support of institutions of interest, and the breaking with proposals for changes in the current institutions of the touristic route (Jacometti et al., 2014; Canning \& O'Dwyer, 2016; Lawrence et al., 2009).

The analysis showed that the institutional creation work developed by the actors in the organizational field was carried out with greater intensity, showing a great capacity to promote actions aimed at creating new norms and rules in the organizational field.

The institutional creation work, classified in the regulatory institutional pillar of Scott (2008) was the typology that had the highest incidence in the data analyzed, showing that the main actions carried out by the actors aimed at creating rules, defining identities, and defending the current institutions. By seeking political support, they sought to provide legitimacy to the touristic route. The analyzes inherent to this type of institutional work allows concluding that the actors have a great capacity for an agency when it comes down to the creation of new institutions and often seek political support for the realization of collective projects.

The institutional maintenance work analyzed showed that the actions performed by the actors inserted in the organizational field are related to the strong resistance to change to neutralize the possible threats that may alter the status quo in which the companies find themselves (Micelotta \& Washington, 2013). The study demonstrated that there is no preservation of the normative foundations to sustain and maintain the myths of the TRSC implementation process, as described by Lawrence and Suddaby (2006), evidenced by the lack of knowledge about the TRSC's formalization history, mainly of the enterprises belonging to the municipality of Campina Grande do Sul. This fact can be justified by the late adhesion of enterprises from Campina Grande do Sul in the touristic cluster, which occurred after its formalization.

Thus, it can be inferred that the recognition of the collective efforts that were undertaken by the actors to promote the implementation of the TRSC as an organized touristic route helped in the process of institutional maintenance, triggering a greater commitment from the participants in the organizational field when they realized that the current condition was not by chance, but it was the result of hard work, time and public investments by government actors who believed in the tourism potential of the projects and the region.

The analysis also showed that the proposal to implement a Tourism LPA in the cluster sounded like a threat to the current institutions, causing TRSC members to act aiming at maintaining the current conjuncture of the organizational field through the establishment of coercive barriers to institutional change (Lawrence \& Suddaby, 2006). As a result, they rejected the technical support offered by professors and researchers from higher education institutions who were willing to help in the process of formalization of the cluster (Jacometti et al., 2017).

As for the institutional disruption work present in the TRSC, it was observed that the efforts and actions carried out by the actors are linked to the lack of interests served by the organization (Lawrence \& Suddaby, 2006), as was the case of the business owners that were disassociated from the touristic route and acted by attacking or undermining existing institutions (Jacometti et al., 2014; Canning \& O'Dwyer, 2016; Lawrence et al., 2009).

It was also observed that the disruption actions were also carried out by social agents to preserve the current context (Coraiola et al., 2015), which was evidenced by the group's decline in undertaking efforts aimed at formalizing a tourist LPA based in the TRSC creation efforts. Actions aimed at promoting the deinstitutionalization of norms and rules were also identified, due to political and social pressures (Oliver, 1992) triggered by the members of the TRSC, who dissatisfied with the results and perceived gains, worked towards breaking the existing institutions and returning to their past status of isolated tourism businesses.

Finally, the data showed that, although there was a success in formalizing the route, it was not institutionalized, which is shown by the decrease in the number of businesses that remained as members of the TRSC, by the removal of the route's website from the internet, by the lack of support of the entrepreneurs who projected in third parties the responsibility for failure in the enterprise itself and for the rupture of the proposal to implement a Tourism LPA, which would bring greater visibility and organization. Such factors demonstrated that the TRSC is indeed formalized but was not fully implemented and institutionalized because of the institutional work for maintaining the previous status quo and disrupting it after they could not meet their expectations of gains from the formalization of the TRSC as a touristic route.

The main empirical and practical contribution of this study was identifying the types of institutional work and reconciling the typologies of Lawrence and Suddaby (2006) and Scott (2008), based on the model developed by Jacometti (2013), which allows understanding how tourism routes can be created, maintained and even disrupted 
by the collective action of the region's business owners, chamber of commerce, third parties, and government actors. It has practical implications for public policymakers and for organizational actors aiming at establishing and institutionalizing a tourism local productive arrangement in rural areas, which are considered a source of regional economic development. New avenues for studies are also open after this research. For example, studies can be carried out for investigating how actors become empowered and legitimate to conduct such institutional entrepreneurship projects when the tourist route is not induced by government actors, but when collective action emanates from the business owners themselves.

\section{ACKNOWLEDGEMENTS}

The authors are thankful for the Editor-in-Chief and two anonymous reviewers for their constructive suggestions on this article. This project was partly supported by a research grant funded by the National Council for Scientific and Technological Development of Brazil (CNPq).

\section{REFERENCES}

Ayhan, C. K., Taşlı, T. C., Özkök, F., \& Tatlı, H. (2020). Land-use suitability analysis of rural tourism activities: Yenice, Turkey. Tourism Management, 76, 1-11. https://doi.org/10.1016/j.tourman.2019.07.003

Aragão, I. R., \& Santos, G. N. (2017). Fazendas, agricultura familiar e antigos engenhos de açúcar para viabilidade do turismo rural no litoral sul de Sergipe/Brasil. Revista de Turismo Contemporâneo, 5(2), 260-277.

Baratter, M. A., Ferreira, J. M., \& Costa, M. C. (2010). Empreendedorismo institucional: Características da ação intencional. Perspectivas Contemporâneas, 5(ed. spe.), 237-266.

Bardin, L. (2009). Análise de conteúdo. Lisboa: Edições 70.

Bem Paraná. (2008). Caminho da serra resgata estradas históricas que ligam litoral ao planalto. Retrieved May 19, 2018. Available from: https://www.bemparana.com.br/noticia/60963/

Beni, M. C. (1999). Política e estratégia do desenvolvimento regional: Planejamento integrado e sustentável do turismo. Revista Turismo em Análise, 10(1), 7-17. https://doi.org/10.11606/issn.1984-4867.v10i1p717

Bryman, A., \& Bell, E. (2011). Business research methods. 3rd ed. New York: Oxford University Press.

Canning, M., \& O'Dwyer, B. (2016). Institutional work and regulatory change in the accounting profession. Accounting, Organizations and Society, 54, 1-21. https://doi.org/10.1016/j.aos.2016.08.001

Carvalho, F. R. T. (2015). Turismo e patrimônio cultural material. Cultur: Revista de Cultura e Turismo, 9(1), 143159.

Cintra, R. F., Amâncio-Vieira, S. F., Costa, B. K. (2016). Stakeholder theory and sociological institutionalism: additions to tourism analysis of Londrina-PR. Revista Iberoamericana de Turismo, 6(1), 165-186.

Coraiola, D. M., Jacometti, M., Baratter, M. A., \& Gonçalves, S. A. (2015). Conciliando agência e contexto na dinâmica da mudança institucional. Cadernos EBAPE.BR, 13(4), 701-726. https://doi.org/10.1590/167939518879

Denzin, N. K., \& Lincoln, Y. S. (2006). Introdução: A disciplina e a prática da pesquisa qualitativa. In N. K. Denzin, \& Y. S. Lincoln, O planejamento da pesquisa qualitativa: Teorias e abordagens. 2nd ed. Porto Alegre, RS, Artmed, 15-41.

DiMaggio, P. J., \& Powell, W. W. (1991). Introduction. In W. W. Powell, \& P. J. DiMaggio, The new institutionalism in organizational analysis (pp. 1-38). Chicago: Chicago University Press.

DiMaggio, P. J., \& Powell, W. W. (2005). A gaiola de ferro revisitada: Isomorfismo institucional e racionalidade coletiva nos campos organizacionais. Revista de Administração de Empresas, 45(2), 74-89.

Eisenhardt, K. M. (1988). Agency and institutional theory explanations: The case of retail sales compensation. Academy of Management Journal, 31(3), 488-511. https://doi.org/10.5465/256457

Endres, A. V., \& Pakman, E. T. (2019)._Governability of tourist policies: the role of the participation spaces in the perspective of the network analysis and the institutional theory. Revista Brasileira de Pesquisa em Turismo, 13(1), 1-18. https://doi.org/10.7784/rbtur.v13i1.1431

Falaster, C., Zanin, L. M., Guerrazzi, L. A. (2017). Institutional theory in tourism research: new opportunities from an evolving theory. Revista Brasileira de Pesquisa em Turismo, 11(2), $270-293$. https://doi.org/10.7784/rbtur.v11i2.1310 
Freixo, M. (2009). Metodologia científica: Fundamentos, métodos e técnicas. Lisboa: Instituto Piaget.

Fundeanu, D. D. (2015). Innovative regional cluster, model of tourism development. Procedia Economics and Finance, 23, 744-749. https://doi.org/10.1016/S2212-5671(15)00501-8

Guimarães, C. R. F. F., \& Morano, C. B. (2020). Revisão sistemática de trabalhos acadêmicos sobre turismo e emprego no Brasil, entre os anos de 2010-2020. Revista Iberoamericana de Turismo, 10(2), 123-135. https://doi.org/10.2436/20.8070.01.182

Gibbs, G. (2007). The Sage qualitative research kit: Analyzing qualitative data. London: Sage.

Hasselbladh, H., \& Kallinikos, J. (2000). The project of rationalization: a critique and reappraisal of neo-institutionalism in organizational studies. Organizational Studies, 21(4), 697-720. https://doi.org/10.1177\%2F0170840600214002

Hoffman, A. J. (1999). Institutional evolution and change: Environmentalism and the US chemical industry. Academy of Management Journal, 42(4), 351-371. https://doi.org/10.5465/257008

Jacometti, M. (2013). Institutional work na conformação do conhecimento difundido em redes interorganizacionais: Estudo de APLs no Estado do Paraná. PhD thesis, Universidade Federal do Paraná, Curitiba, PR, Brasil. http://hdl.handle.net/1884/34682

Jacometti, M., Gonçalves, S. A., \& Castro, M. (2014). Institutional work e conhecimento em redes interorganizacionais: Uma proposta para investigar APLs. Revista de Administração Mackenzie, 15(6), $17-47$. https://doi.org/10.1590/1678-69712014/administracao.v15n6p17-47

Jacometti, M., Gonçalves, S. A., Minghini, L., Bonfim, L. R. C., Lago, E. C. W. (2017). Institucionalização de arranjo produtivo local: uma proposição metodológica. Perspectivas Contemporâneas, 12(3), 33-52.

Jafari, J. (1987). Tourism models: The sociocultural aspects. Tourism Management, 8(2),151-159. https://doi.org/10.1016/0261-5177(87)90023-9

Lago, E. C. W., Jacometti, M., Cavalcante, T. N., Bonfim, L. R. C., \& Oliveira, L. C. (2018). Estratégias de empreendedorismo institucional numa rede de empresas de turismo. Revista Eletrônica de Estratégia \& Negócios, 11(3), 136-168.

Lascoumes, P., \& Le Galès, P. (2014). Sociología de la acción pública. Ciudad de Mexico: El Colegio de Mexico, CEDUA.

Laville, C., \& Dionne, J. (1999). A construção do saber: Manual de metodologia da pesquisa em ciências humanas. Belo Horizonte, MG: Universidade Federal de Minas Gerais.

Lawrence, T. B., \& Suddaby, R. (2006). Institutions and institutional work. In S. R. Clegg, C. Hardy, \& W. R. Nord (Eds.), Handbook of organization studies (2nd ed., pp. 215-254). London: Sage.

Lawrence, T. B., Suddaby, R., \& Leca, B. (2009). Institutional work: Actors and agency in institutional studies of organizations. Cambridge: Cambridge University Press.

Lima, M. A. G., Irving, M. A., \& Abreu, M. M. (2017). Políticas públicas de cultura e turismo: uma relação mal resolvida? Cultur: Revista de Cultura e Turismo, 11(1), 174-201.

Machado-da-Silva, C. L., Guarido Filho, E. R., \& Rossoni, L. (2006). Campos organizacionais: Seis diferentes leituras e a perspectiva de estruturação. Revista de Administração Contemporânea, 10(spe.), 159-196. https://doi.org/10.1590/S1415-65552006000500009

Malta, G. A. P., Braga, S. S., \& Barbosa, M. F. P. (2019). Conceptions of economic development and the understanding of the role of tourism in poverty reduction. Revista Brasileira de Pesquisa em Turismo, 13(2), $16-31$. https://doi.org/10.7784/rbtur.v13i2.1513

Marietto, M. L., \& Serra, F. A. R. (2019). The role of institutional elements on strategic activities of small business practitioners. International Journal of Entrepreneurship and Small Business, 37(2), 250-270. https://doi.org/10.1504/IJESB.2019.100107

Mazmanian, D. A., \& Sabatier, P. A. (1981). Effective policy implementation. Lexington: Lexington Books.

Medeiros, A. K., Alves, M. A., \& Farah, M. F. S. (2015). Programa cultura viva e o campo organizacional da cultura: Análise de políticas públicas pela perspectiva institucionalista. Revista de Administração Pública, 49(5), 1215-1235. https://doi.org/10.1590/0034-7612130337

Meyer, J. W., \& Rowan, B. (1977). Institutionalized organizations: Formal structure as myth and ceremony. American Journal of Sociology, 83(2), 340-363. https://doi.org/10.1086/226550

Micelotta, E. R., \& Washington, M. (2013). Institutions and maintenance: The repair work of Italian professions. Organization Studies, 34(8), 1137-1170. https://doi.org/10.1177/0170840613492075 
Minayo, M. C. S. (2008). O desafio do conhecimento: Pesquisa qualitativa em saúde. 11st ed. São Paulo: Hucitec.

Ministério do Desenvolvimento Agrário. (2017). Turismo rural: Convite a conhecer a vida do campo. Retrieved Mar. 22, 2018. Available from: http://www.mda.gov.br/sitemda/noticias/turismo-rural-convite-conhecer-vidado-campo

Ministério do Turismo. (2007). Programa de regionalização do turismo - roteiros do Brasil: módulo operacional roteirização turística. Retrieved Apr. 29, 2018. Available from: http://www.regionalizacao.turismo.gov.br/images/roteiros brasil/roteirizacao turistica.pdf

Ministério do Turismo. (2015). Programa talentos do Brasil rural. Retrieved Jun. 26, 2017. Available from: http://www.turismo.gov.br/acesso-a-informacao/63-acoes-e-programas/4888-programa-talentos-do-brasil-rural.html

Ministério do Turismo. (2016). Edital: talentos do Brasil rural. Retrieved May 12, 2018. Available from: http://www.turismo.gov.br/assuntos/80-editais/selecoes-e-chamadas-de-projetos/5942-talentos-brasilrural.html

Moisander, J. K., Hirsto, H., \& Fahy, K. M. (2016). Emotions in institutional work: A discursive perspective. Organization Studies, 37(7), 963-990. https://doi.org/10.1177\%2F0170840615613377

Mozzato, A. R., \& Grzybovski, D. (2011). Análise de conteúdo como técnica de análise de dados qualitativos no campo da administração. Revista de Administração Contemporânea, 15(4), $731-747$. https://doi.org/10.1590/S1415-65552011000400010

Novelli, M., Schmitz, B. \& Spencer, T. (2006). Networks, clusters and innovation in tourism: A UK experience. Tourism Management, 27(6), 1141-1152. https://doi.org/10.1016/j.tourman.2005.11.011

Oliver, C. (1992). The antecedents of deinstitutionalization. Organization Studies, 13(4), 563-588. https://doi.org/10.1177/017084069201300403

Padilha, A. C. M., Corte, A. D., \& Souza, M. (2019). Diversificação de Sustento Rural a partir da Exploração do Turismo Rural: o caso da Rota das Salamarias, Marau, Rio Grande do Sul. Turismo e Sociedade, 12(2), 84109. https://doi.org/10.5380/tes.v12i2.68230

Pimentel, T. D., Carvalho, F. C. C., Pimentel, M. P. C. (2019). The Institutionalization Process of the Formal Structures of Tourism Research (FSTR) in Brazil. Revista Brasileira de Pesquisa em Turismo, 13(3), $16-35$. https://doi.org/10.7784/rbtur.v13i3.1493

QBCAMP. Associação Industrial e Comercial de Quatro Barras e Campina Grande do Sul. (2018). Apresentação. Retrieved Jun. 5, 2018. Available from: http://www.qbcamp.com.br

Ribeiro, T. L. S., Kevin, K. S., Costa, B. K., \& Urdan, A. T. (2020). Percepç̃oes de stakeholders sobre o turismo: um estudo no município de São Sebastião, SP. Turismo: Visão e Ação, 22(2), 334-354. https://doi.org/10.14210/rtva.v22n2.p334-354

Ruhanen, L., \& Cooper, C. (2004). Applying a knowledge management framework to tourism research. Tourism Recreation Research, 29(1), 83-87. https://doi.org/10.1080/02508281.2004.11081434

Sanches, A. C., Sauer, L., Binotto, E., \& Espejo, M. M. B. (2018)._Análise dos Estudos sobre Indicadores de Sustentabilidade no Turismo: uma revisão integrativa. Revista Turismo em Análise, 29(2), 292-311. https://doi.org/10.11606/issn.1984-4867.v29i2p292-311

Santos, T. S., \& Pereira, R. S. (2018). Governance of Tourism in Campo das Vertentes, MG, Brazil: a path to regional development? Revista Brasileira de Pesquisa em Turismo, 12(2), 83-111. https://doi.org/10.7784/rbtur.v12i2.1415

Scótolo, D., \& Panosso Netto, A. (2015). Contribuições do turismo para o desenvolvimento local. CULTUR: Revista de Cultura e Turismo, 9(1), 36-59.

Scott, W. R. (1994). Institutions and organizations: Toward a theoretical synthesis. In W. R. Scott, \& J. W. Meyer (Eds.), Institutional environments and organizations. Thousand Oaks: Sage.

Scott, W. R. (2002). Organizations (5th ed.). Englewood Cliffs: Prentice-Hall.

Scott, W. R. (2004) Institutional theory. In G. Ritzer (Ed.), Encyclopedia of social theory (pp. 408-414). Thousand Oaks, Sage.

Scott, W. R. (2008). Institutions and organizations: Ideas and interests (3rd ed.). Los Angeles: Sage.

Scott, W. R., \& Meyer, J. W. (1983). The organization of societal sectors. In J. W. Meyer, \& W. R. Scott (Orgs.). Organizational environments. Beverly Hills, Sage. 
SEBRAE. Serviço Brasileiro de Apoio às Micro e Pequenas Empresas. (2014). Talentos do Brasil: Catálogo de produtos e serviços. Porto Alegre: SEBRAE.

Shah, S. (2006). Sharing the world: The researcher and the researched. Qualitative Research, 6(2), 207-220. https://doi.org/10.1177/1468794106062710

Sohn, A. P., Silvestrini, C., Fiuza, T. F., \& Limberger, P. F. (2017). The elements that characterize the tourism cluster in Balneário Camboriú, SC, Brazil. Revista Brasileira de Pesquisa em Turismo, 11(1), 154-174. http://doi.org/10.7784/rbtur.v11i1.1201

Stacey, M. (1977). Methods of social research. Oxford: Pergamon Press.

Stake, R. E. (2009). A arte da investigação com estudos de caso (2nd ed.). Lisboa: Fundação Calouste Gulbenkian.

Tonini, H., \& Dolci, T. S. (2020). Turismo Rural e Novos Mercados para Produtos Alimentares Agroecológicos: Estudo de Caso da Rota Via Orgânica. Rosa dos Ventos: Turismo e Hospitalidade, 12(3), 537-554.

Triviños, A. N. S. (1987). Introdução à pesquisa em Ciências Sociais: A pesquisa qualitativa em Educação. São Paulo: Atlas.

Van de Ven, A., \& Poole, M. S. (1995). Explaining development and change in organizations. Academy of Management Review, 20(3), 510-540. https://doi.org/10.5465/amr.1995.9508080329

Vilelas, J. (2009). Investigação: O processo de construção do conhecimento. Lisboa: Edições Sílabo.

\section{Author's informations}

\section{Márcio Jacometti}

$\mathrm{PhD}$ in Management (Strategy and Organizational Analysis) from the Federal University of Paraná (UFPR). He is currently Professor at the Postgraduate Program in Administration at the Federal Technological University of Paraná (UTFPR), Curitiba, PR, Brazil. Contribuição: Research design, literature review, data analysis, and discussion.

E-mail: jacometti@utfpr.edu.br

ORCID: https://orcid.org/0000-0001-9740-7218

\section{Ellen Correa Wandembruck Lago}

PhD student in Planning and Public Governance at the Federal Technological University of Paraná (UTFPR).

Contribuição: Literature review, data collection, data analysis, and discussion.

E-mail: ellencwlago@hotmail.com

ORCID: https://orcid.org/0000-0001-5378-2454

\section{Leandro Rodrigo Canto Bonfim}

$\mathrm{PhD}$ in Management (Innovation and Technology) from the Federal University of Paraná (UFPR). He is currently and Assistant Collaborating Professor at the State University of Paraná (Unespar), Campus Paranaguá, PR, Brazil.

Contribuição: Literature review, translation, and discussion.

E-mail: bonfim@unespar.edu.br

ORCID: https://orcid.org/0000-0003-0323-7911 